\title{
Proinsulinoma causing severe hypoglycemia in a patient with type 1 diabetes mellitus
}

\author{
Leonard A. Bertheau ${ }^{1}$, Robert C. Herceg ${ }^{2}$, Ramiro Malgor ${ }^{3}$, Aili Guo ${ }^{4}$, Frank L. Schwartz ${ }^{4}$ \\ 1. Adventist Health Medical Group Diabetes and Endocrine Center, Portland, USA. 2. Dept. of Pathology, Camden Clark \\ Memorial Hospital, Parkersburg, USA. 3. Department of Biomedical Sciences, the Diabetes Institute, Ohio University \\ Heritage College of Osteopathic Medicine, Athens, Greece. 4. Department of Specialty Medicine at the Ohio University \\ Heritage College of Osteopathic Medicine, $\mathrm{OH}$, The Diabetes Institute, Ohio University, Athens, Greece.
}

Correspondence: Frank L Schwartz. Address: 331 Academic Research Center Ohio University Heritage College of Osteopathic Medicine, Athens, OH, Greece. E-mail: schwartf@ohio.edu

Received: January 9, 2014

Accepted: March 23, 2014

Online Published: March 27, 2014

DOI : $10.5430 /$ crcp.v1n2p21

URL: http://dx.doi.org/10.5430/crcp.v1n2p21

\section{Abstract}

Case presentation: A 49 year male a 35 year history of Type 1 Diabetes Mellitus (T1DM) was evaluated for recurrent episodes of hypoglycemia. After being weaned off of all exogenous insulin, the patient continued to have frequent and severe episodes of hypoglycemia often associated with seizures.

Results: During an observed hypoglycemic reaction in our office he was found to have a serum glucose level of $64 \mathrm{mg} / \mathrm{dl}$, a serum insulin level of $64 \mu \mathrm{IU} / \mathrm{ml}$ (reference range is $<17 \mu \mathrm{IU} / \mathrm{ml}$ ) and a C-peptide level of $0.6 \mathrm{ng} / \mathrm{ml}$ (reference range is $0.8 \mathrm{ng} / \mathrm{ml}-3.1 \mathrm{ng} / \mathrm{ml}$ ). Serum and urine sulfonylurea levels were negative. During a formal diagnostic 72 hour fast, he developed severe hypoglycemia within four hours of beginning the fast and seized. No diagnostic laboratory studies were obtained during the hypoglycemic event! He underwent surgical exploration, where a $0.8 \mathrm{~cm}$ well-differentiated, islet cell tumor was resected. Following resection of the tumor, the spontaneous hypoglycemia resolved, and maintenance exogenous insulin was reinstituted. Histoimmunochemical staining was positive for chromogranin, synaptophysin, amylin, and proinsulin but negative for insulin. Immunostaining of the tumor was also positive for Toll-like receptors-3 (TLR3) and Wnt5a.

Conclusion: This is the first case report of a patient with a long history of T1DM who developed a recurrent hypoglycemia due to a proinsulin-secreting islet cell tumor which resolved following its resection.

\section{Key words}

Hypoglycemia, Type 1 diabetes mellitus, Proinsulinoma

\section{I ntroduction}

Type 1 diabetes mellitus (T1DM) results from the destruction of pancreatic beta cells resulting in insulin deficiency. It usually results of an autoimmune destructive process (pattern A) but can be idiopathic in etiology (pattern B) ${ }^{[1,2]}$. Hypoglycemia is a common side-effect of insulin therapy in T1DM but this is usually due to a mismatch between the timing of food, physical activity, and insulin dosage; not endogenous insulin secretion ${ }^{[3]}$. Insulinomas are rare islet cell tumors derived primarily from beta cells which autonomously synthesize and secrete inappropriate and excessive amounts of proinsulin and/or insulin resulting in the development of spontaneous hypoglycemia ${ }^{[3,4]}$. The incidence of insulinoma 
is approximately 3-10 cases per million persons per year in the United States ${ }^{[4,6]}$ and proinsulin-only secreting islet cell tumors causing hypoglycemia are even rarer ${ }^{[5-8]}$. The diagnosis of an insulinoma or proinsulinomas is confirmed biochemically with a simultaneous low blood sugar and inappropriately elevated serum insulin, pro-insulin and/or c-peptide levels ${ }^{[4,9,10]}$. Localization of the tumor is usually established by imaging or angiography, and the definitive treatment is surgical resection of the tumor followed by resolution of the hypoglycemia ${ }^{[1]]}$.

A genetic basis for some insulinomas has been linked to the gene for Multiple Endocrine Neoplasia I (MEN1) and k-ras mutations, however chronic inflammation is also known to be oncogenic and may contribute to the malignant transformation in many different types of tumors ${ }^{[12-14]}$. Toll-like receptors (TLR) are a family of cell surface pattern recognition receptors in immune cells which recognize signature molecules of different environmental pathogens and are important components of the innate and acquired immune system ${ }^{[15]}$. The Wingless (Wnt) family of secreted glycoproteins control early developmental processes including cellular migration, differentiation, and proliferation but are also involved in oncogenesis and tumor spread ${ }^{[16]}$. Recently, we demonstrated that high basal expression of TLR3 and Wnt5a are coordinately expressed in tumors that have undergone malignant transformation and their determination immunohistochemically might serve as a diagnostic marker ${ }^{[17,18]}$.

In this report, we describe the first case of a presumptive proinsulinoma which occurred in a patient with 35 year history of T1DM who presented with severe, recurrent hypoglycemia which went away following the resection of a proinsulin secreting islet cell tumor of the pancreas.

\section{Case report}

A 49-year old male patient with a 35 year history of T1DM who had previously been managed by FLS was referred back to the Endocrine/Diabetes Center because of the recent development of severe, recurrent episodes of hypoglycemia; often resulting in multiple daily seizures. He had developed T1DM at the age of 14, had been fairly well maintained on exogenous insulin, and had previously experienced only infrequent hypoglycemia prior to his evaluation. However, over the previous 6-8 month period he had begun developing frequent episodes of severe hypoglycemia. His father who was a retired physician had gradually reduced and then stopped all exogenous insulin; however the hypoglycemia and seizures continued. The hypoglycemia would occur spontaneously, often at night, and his father was trying to prevent it by feeding him every three to four hours; day and night, supplemented with maple syrup. In spite of this, he often required multiple glucagon injections per day.

Past medical history included: a mild congenital cognitive disorder, Wilm's Tumor treated with right nephrectomy plus external radiation to the kidney bed at age 3 years, and development of T1DM at age 14. Medications included: diltiazem; $240 \mathrm{mg}$, furosemide; $40 \mathrm{mg}$, and lisinopril; $20 \mathrm{mg}$. He had taken no exogenous insulin in 6 months prior to the visit. Social history revealed that he was single, unemployed, and lived with his elderly parents. His father who was a retired physician was his sole care taker and answered all pertinent health-related questions. Review of systems was primarily related to the recurrent hypoglycemia and seizures. He had been hospitalized on three occasions in the past four months with severe hypoglycemia and seizures, as well has multiple emergency room visits and EMS calls to the house. Physical exam revealed a well-developed middle age male with an obvious cognitive deficit. Vital signs were normal, BMI was 25.6 and there was a well healed right flank scar. The right abdominal musculature was somewhat atrophic from previous external radiation. We suspected Munchausen Syndrome by proxy at the first appointment.

During his first clinical evaluation in our clinic he experienced an episode of hypoglycemia and labs obtained at that time demonstrated a serum glucose: $64 \mathrm{mg} / \mathrm{dl}$, insulin: serum $64 \mu \mathrm{IU} / \mathrm{ml}$ (reference range is $<17 \mu \mathrm{IU} / \mathrm{ml}$ ) and C-peptide: $0.6 \mathrm{ng} / \mathrm{ml}$ (reference range is $0.8 \mathrm{ng} / \mathrm{ml}-3.1 \mathrm{ng} / \mathrm{ml}$ ). Serum and urine sulfonylurea levels were negative as well anti-insulin antibodies. A previous CT scan of the abdomen was reported as negative for pancreatic tumor. Based on these findings, the patient was admitted to a local community hospital with no attending endocrinologists for a formal, 
supervised 72 hour fast based on specific orders we had provided his attending physician. Within four hours of beginning the fast however, the patient developed severe hypoglycemia and a seizure. The fast was stopped by the attendant nurse who administered an ampule of D50. A stat fingerstick glucose level of $52 \mathrm{mg} / \mathrm{dl}$ was obtained, but inadvertently, no insulin, pro-insulin, or c-peptide levels were obtained at the time of the hypoglycemia! Without any discussion with us by his attending physician, he was seen by a general surgeon and underwent abdominal exploration the following morning. At laparoscopy, a small mass was palpated in the mid-pancreas/tail and a tumor was resected. Following the partial pancreatectomy, the patient's glucose levels became elevated, he had to be placed back on exogenous insulin in doses which were equivalent to his previous maintenance doses, has had no further severe hypoglycemia in the last six years.

\section{Methods}

Serum insulin and C-peptide blood levels were performed by Lab Corp Reference Laboratories. Formalin fixed paraffinembedded tissue sections were cut at $5 \mu \mathrm{m}$ for Hematoxylin eosin (HE) stain and immunohistochemistry (IHC). Chromogranin and synaptophysin staining were performed by Camden Clark Medical Center. Amylin, insulin, glucagon, pro-insulin, TLR3, and Wnt5a were performed at Ohio University. Briefly, following antigen retrieval, primary antibodies for anti-human insulin and anti-mouse insulin (1/100), anti-human amylin (1/200), anti-human proinsulin (1/500), from abcam (Cambridge MA); anti-TLR3 (3.0 $\mu \mathrm{g} / \mathrm{ml})$ from Santa Cruz Biotechnology Inc. (California CA), anti-human Wnt5a $(1 / 500)$, were incubated overnight at $4 \mathrm{oC}$. Next day, secondary antibody specific for each primary antibody was incubated for one hour followed by DAB. The specificity was confirmed by incubation consecutive tissue section with the corresponding isotype control for each primary antibody.

Figure. Hematoxylin and Eosin (HE) staining and immunostaining for insulin, chromogranin, synaptophysin, pro-insulin, amylin, TLR3 and Wnt5a.

A includes pancreatic tissue on the left and top of the picture with a central tumor nodule measuring $0.8 \mathrm{~cm}$ in greatest dimension; bar $=500 \mu \mathrm{m}$. At higher magnification; B shows an infiltrating tumor composed of small monotonous cells arranged in cords, ribbons, and trabecular formations in a desmoplastic stroma; bar = $100 \mu \mathrm{m} . \mathrm{C}$ at higher magnification, the nuclei of the tumor cells are round to slightly ovoid and show specked chromatin patterns; bar $=25 \mu \mathrm{m}$. D demonstrates the presence of no immunostaining for insulin using multiple anti-insulin antibodies at high power magnification; $b a r=25 \mu \mathrm{m}$. E and $\mathrm{F}$ demonstrates immunostaining of tumor cells are reactive for both chromogranin and synaptophysin; bar $=25 \mu \mathrm{m}$. These findings are consistent with well differentiated neuroendocrine neoplasm. $\mathrm{G}$ and $\mathrm{H}$ show immunostaining for proinsulin and amylin respectively, bar $=25 \mu \mathrm{m}$ confirming it was a beta cell tumor.

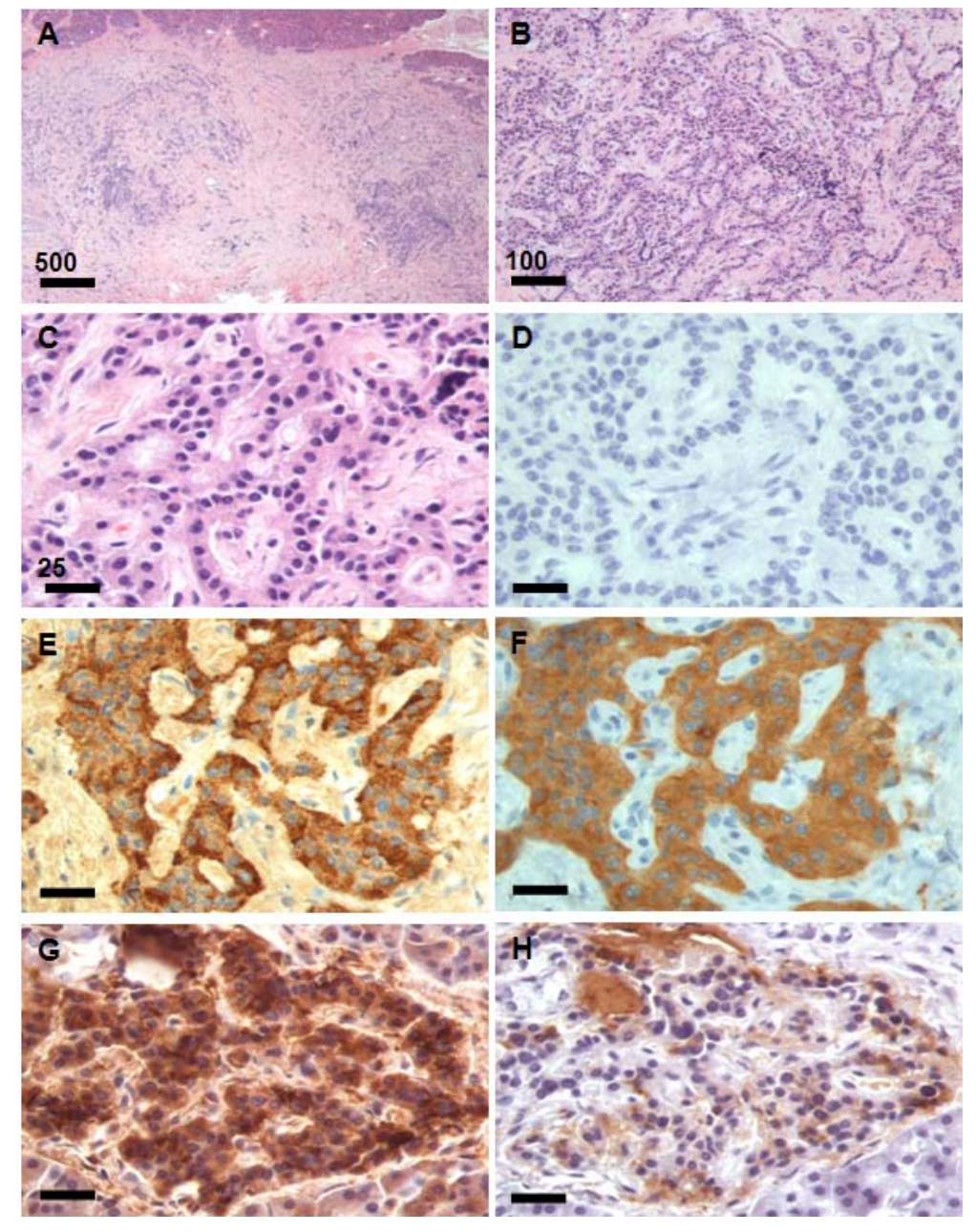




\section{Results of staining}

HE staining (see Figure A-C) of the $4.5 \mathrm{~cm} \times 2.5 \mathrm{~cm} \times 1.2 \mathrm{~cm}$ distal pancreatic tissue revealed a small tumor measuring $0.8 \mathrm{~cm}$ in diameter. It was a well demarcated but non- encapsulated tumor. Within the tumor two components are recognized: small, uniform epithelial cells arranged in trabecular, palisading, ribbon or cord pattern, surrounded by extensive fibrous tissue (see Figure A-C). The epithelial cells showed no pleomorphism, but contain eosinophilic cytoplasm; and the nuclei were round and demonstrated a speckled chromatin pattern. No mitotic figures were seen. HE staining of pancreatic tissue surrounding the tumor revealed fibrous and focally hyalinized stroma (see Figure A) IHC staining revealed that the epithelial cells in the tumor were nonreactive for human and mouse insulin using multiple commercial insulin antibodies (see Figure D) but reactive for pro-insulin (see Figure G) and amylin (see Figure H) suggesting the tumor was secreting proinsulin. The cells showed strong reactivity for both chromogranin (see Figure E) and synaptophysin (see Figure F), also consistent with a neuroendocrine cell origin. Immunostaining for TLR3 (see Figure G) was positive in both the cytoplasm of neoplastic islet cells and the stroma, while Wnt5a (see Figure H) was only weakly positive in the cytoplasm of the neoplastic cells.

\section{Discussion}

This a very unusual case report of a person with long-standing T1DM who spontaneously developed severe, spontaneous hypoglycemia even after being weaned off of exogenous insulin. He had an inappropriately elevated serum insulin level during at least one of these hypoglycemic episodes, was found to have an islet cell tumor, which was resected, and following resection of the tumor the hypoglycemia ceased. Even more unusual is the finding that the tumor demonstrated immunostaining for proinsulin but not insulin in spite of us trying three different commercial preparations. There have been two previous cases of insulinomas occurring in patients preexisting T1DM ${ }^{[5,7]}$ with multiple cases of insulinomas arising individuals with type 2 diabetes mellitus reported ${ }^{[19]}$. There have also been several cases of spontaneous hypoglycemia caused by proinsulinomas ${ }^{[5,7,20]}$; however this is the first case report of a proinsulinoma developing in a patient with pre-existing T1DM.

In this case of a person with a 35 year history of T1DM most of his beta cells were destroyed although few were observed on $\mathrm{H} \& \mathrm{E}$ but insulin was not present by immunostaining (not shown). Histologically, the nuclei of the of the $8 \mathrm{~mm}$ islet cell tumor cells were round to slightly ovoid and show specked chromatin patterns which was interpreted pathologically as a benign islet cell tumor. Immunostaining of the islet cell tumor was positive for glucagon, amylin, and proinsulin but not insulin indicating that it was probably a functional islet cell tumor. The failure to detect insulin immunostaining in the tumor with two different anti-human insulin antibodies and one anti-mouse insulin antibody is troubling, but could be the result of the rapid release of the hormone from the tumor or a molecular variant not detected by the antibodies we used for immunostaining ${ }^{[21,22]}$. The finding of strongly positive proinsulin immunostaining in the tumor suggests that it was possibly the major peptide secreted by this tumor causing the hypoglycemia; although a serum insulin level of $64 \mu \mathrm{IU} / \mathrm{ml}$ (reference range is $<17 \mu \mathrm{IU} / \mathrm{ml}$ ) was inappropriately elevated for a serum glucose level of $64 \mathrm{mg} / \mathrm{dl}$. However, again our failure to obtain a serum proinsulin at our initial evaluation precludes a definite answer. None the less, the fact that the hypoglycemia resolved following the islet cell tumor resection, has not reoccurred over the past six years, and that the patient immediately required insulin replacement following its resection does support our assertion that this was indeed a functional proinsulinoma causing his severe hypoglycemia.

We also demonstrated immunostaining for TLR3 and Wnt-5a in the islet cell tumor. The significance of this finding is unknown; however, TLR3 and Wnt-5a are coordinately expressed in certain tumor lines which have undergone malignant transformation ${ }^{[17,18]}$ but not in benign tumors. Chronic inflammation within the pancreas is thought to contribute to the increased prevalence of pancreatic cancer in persons with $\mathrm{T} 2 \mathrm{DM}{ }^{[23,24]}$. Although he had received external radiation therapy at age 3 to his right kidney bed, could the chronic inflammation from the previous destruction of the beta cells in 
the pancreas (observed in the surrounding pancreatic tissue) contributed to the development of a functioning proinsulinsecreting islet cell tumor in this patient with long-standing T1DM?

As stated earlier, the major weakness of this case is the fact that serum specimens for insulin, proinsulin, and c-peptide levels were not obtained during the hypoglycemic event which occurred during the supervised 72 hour fast. We also failed to obtain a proinsulin level during the hypoglycemic episode which we witnessed in our office at the initial evaluation and now stress the importance of obtaining a proinsulin level during any evaluation of hypoglycemia. Supporting our contention was the inappropriately elevated serum insulin level at $64 \mu \mathrm{IU} / \mathrm{ml}$ (reference range is $<17 \mu \mathrm{IU} / \mathrm{ml}$ ) with a glucose of $64 \mathrm{mg} / \mathrm{dl}$. The C-peptide obtained at the same time was not as excessively elevated as expected given the insulin level $0.6 \mathrm{ng} / \mathrm{ml}$ (reference range is $0.8 \mathrm{ng} / \mathrm{ml}-3.1 \mathrm{ng} / \mathrm{ml}$ ) but still inappropriately high for a glucose level of $64 \mathrm{mg} / \mathrm{dl}$. Other insulinoma case reviews have reported lower C-peptide levels than would be expected ${ }^{[25,26]}$ and possible explanations are that C-peptide can be rapidly degraded by cathepsin B in the islet tumor or not secreted into the serum ${ }^{[21]}$.

\section{Conclusion}

We present a case of a patient with a 35 year history of T1DM who developed symptomatic recurrent hypoglycemia from a functional proinsulin staining islet cell tumor which resolved following its surgical resection.

\section{Research support}

J O Watson Endowed Chair for Diabetes Research at Ohio University Heritage College of Osteopathic Medicine, Athens, $\mathrm{OH}$.

\section{References}

[1] Cnop, M., Welsh, N., Jonas, J.C., Jorns, A., Lenzen, S., Eizirik, D.L. Mechanisms of pancreatic beta-cell death in type 1 and type 2 diabetes: many differences, few similarities. Diabetes. 2005; 54(Suppl 2): S97-107. PMid: 16306347.

http://dx.doi.org/10.2337/diabetes.54.suppl_2.S97

[2] Zipris, D. Innate immunity and its role in type 1 diabetes. Curr Opin Endocrinol Diabetes Obes. 2008; 15: 326-331. PMid: 18594272. http://dx.doi.org/10.1097/MED.0b013e3283073a46

[3] Mathur, A., Gorden, P., Libutti, S.K. Insulinoma. Surg Clin North Am. 2009; 89: 1105-1121. PMid: 19836487. http://dx.doi.org/10.1016/j.suc.2009.06.009

[4] Service, F.J. Diagnosis of insulinoma and the euglycemic hyperinsulinemic clamp technique. Ann Intern Med. 1985; $102: 417-418$. PMid: 2982309. http://dx.doi.org/10.7326/0003-4819-102-3-417

[5] Fadini, G.P., Maran, A., Valerio, A., Meduri, F., Pelizzo, M., Miotto, D., et al. Hypoglycemic syndrome in a patient with proinsulin-only secreting pancreatic adenoma (proinsulinoma). Case Rep Med. 2011; 930904. PMid: 21765847.

[6] Gomez-Perez, F.J., Cuevas-Ramos, D., Valdes, P.A., Aguilar-Salinas, C.A., Mehta, R., Rull, J.A. Beta-cell adenomas without hyperinsulinemia with use of highly specific insulin radioimmunoassays: case report and review of literature. Endocr Pract. 16: 660-663. PMid: 20439243. http://dx.doi.org/10.4158/EP10016.CR

[7] Piovesan, A., Pia, A., Visconti, G., Terzolo, M., Leone, A., Magro, G., et al. Proinsulin-secreting neuroendocrine tumor of the pancreas. J Endocrinol Invest. 2003; 26: 758-761. PMid: 14669832.

[8] Rodriguez, A., Canto, M.I., Makary, M.A. Endoscopic localization and tattooing of a proinsulinoma for minimally invasive resection. Pancreas. 40: 474-477. PMid: 21412118. http://dx.doi.org/10.1097/MPA.0b013e318205e926

[9] Cazabat, L., Chanson, P. [Hypoglycemia and insulinoma]. Ann Endocrinol (Paris). 2009; 70(Suppl 1): S2-11. http://dx.doi.org/10.1016/S0003-4266(09)72470-9

[10] Service, F.J., Nelson, R.L. Insulinoma. Compr Ther. 1980; 6: 70-74. PMid: 6244131.

[11] Gorman, B., Charboneau, J.W., James, E.M., Reading, C.C., Galiber, A.K., Grant, C.S., et al. Benign pancreatic insulinoma: preoperative and intraoperative sonographic localization. AJR Am J Roentgenol. 1986; 147: 929-934. PMid: 3020955. http://dx.doi.org/10.2214/ajr.147.5.929

[12] Oberg, K. Pancreatic endocrine tumors. Semin Oncol. 2010; 37: 594-618. PMid: 21167379. http://dx.doi.org/10.1053/j.seminoncol.2010.10.014

Published by Sciedu Press 
[13] Bazzi, W., Renon, M., Vercherat, C., Hamze, Z., Lacheretz-Bernigaud, A., Wang, H., et al. MEN1 missense mutations impair sensitization to apoptosis induced by wild-type menin in endocrine pancreatic tumor cells. Gastroenterology. 2008; 135: 1698-1709 e1692.

[14] Steele, C.W., Jamieson, N.B., Evans, T.R., McKay, C.J., Sansom, O.J., Morton, J.P., et al. Exploiting inflammation for therapeutic gain in pancreatic cancer. Br J Cancer. 108: 997-1003. PMid: 23385734. http://dx.doi.org/10.1038/bjc.2013.24

[15] Iwasaki, A., Medzhitov, R. Toll-like receptor control of the adaptive immune responses. Nat Immunol. 2004; 5: 987-995. PMid: 15454922. http://dx.doi.org/10.1038/ni1112

[16] Cadigan, K.M. Wnt/beta-catenin signaling: turning the switch. Dev Cell. 2008; 14: 322-323. PMid: 18331712. http://dx.doi.org/10.1016/j.devcel.2008.02.006

[17] Schwartz, A.L., Malgor, R., Dickerson, E., Weeraratna, A.T., Slominski, A., Wortsman, J., et al. Phenylmethimazole decreases Toll-like receptor 3 and noncanonical Wnt5a expression in pancreatic cancer and melanoma together with tumor cell growth and migration. Clin Cancer Res. 2009; 15: 4114-4122. PMid: 19470740. http://dx.doi.org/10.1158/1078-0432.CCR-09-0005

[18] McCall, K.D., Harii, N., Lewis, C.J., Malgor, R., Kim, W.B., Saji, M., et al. High basal levels of functional toll-like receptor 3 (TLR3) and noncanonical Wnt5a are expressed in papillary thyroid cancer and are coordinately decreased by phenylmethimazole together with cell proliferation and migration. Endocrinology. 2007; 148: 4226-4237. PMid: 17525119. http://dx.doi.org/10.1210/en.2007-0459

[19] Dong, A.M., Yuan, Z.F., Zhang, H., Gao, Y.M., Guo, X.H. [Nesidioblastosis in an adult with type 2 diabetes mellitus: a case report]. Beijing Da Xue Xue Bao. 2009; 41: 590-592. PMid: 19829681.

[20] Gama, R.M., V. Wright, J., Teale, J D. Octreatide exacerbated fasting hypoglycemia in a proinsulinmoa; the gastrostatic importance of pancreatic glucagon. Clin Endocrinol (Oxf). 1995; 43: 117-120. http://dx.doi.org/10.1111/j.1365-2265.1995.tb01901.x

[21] Conlon, J.M., Hoog, A, Grimelius, L. Intracellular degredation of C-peptide of proinsulin, in a human insulinoma: identification of sites of cleavage and evidence for cathepsin B. Pancreas. 1965; 10: 167-172. http://dx.doi.org/10.1097/00006676-199503000-00010

[22] Ohneda, A., Sakai, T., Kobayashi, T., Nihei, J. Insulin and C-peptide in plasma and tumor of insulinoma patients. Tohoku J Exp Med. 1983; 139: 73-81. PMid: 6301101. http://dx.doi.org/10.1620/tjem.139.73

[23] Dehayem, Y.M., Phelip, J.M., Kengne, A.P., Choukem, S.P., Benhamou, P.Y., Halimi, S. Impact of diabetes mellitus on clinical presentation and prognosis of pancreatic cancer. Ann Endocrinol (Paris).

[24] Li, D., Tang, H., Hassan, M.M., Holly, E.A., Bracci, P.M., Silverman, D.T. Diabetes and risk of pancreatic cancer: a pooled analysis of three large case-control studies. Cancer Causes Control. 2010; 22: 189-197. PMid: 21104117. http://dx.doi.org/10.1007/s10552-010-9686-3

[25] Service, F.J., O'Brien, P.C., McMahon, M.M., Kao, P.C. C-peptide during the prolonged fast in insulinoma. J Clin Endocrinol Metab. 1993; 76: 655-659. PMid: 8445021.

[26] Fujkura, J., Noguchi, H K, Ebihara, K, Masuzaki, H, Hirata, M, Fujimoto, K, et al. A case of secretin-responsive insulinoma with low serum C-peptide levels. Endocr J. 2007; 54: 113-121. http://dx.doi.org/10.1507/endocrj.K06-148 